Герман М. М., науковий співробітник

Полтавська державна аграрна академія

\title{
ВПЛИВ МІНЕРАЛЬНИХ ДОБРИВ І ДОПОСІВНОЇ ОБРОБКИ НАСІННЯ НА ФОРМУВАННЯ ФІЗИЧНИХ ВЛАСТИВОСТЕЙ ТІСТА ТА ХЛІБОПЕКАРСКІ ПОКАЗНИКИ ЯКОСТІ ЗЕРНА ПШЕНИЦІ М'ЯКОЇ ОЗИМОЇ
}

\section{Рецензент - кандидат сільськогосподарських наук О. В. Міщенко}

\begin{abstract}
Наведено трьохрічні результати вивчення впливу мінеральних добрив і допосівної обробки насіння на формування фізичних властивостей тіста та хлібопекарських показників якості зерна пшениці м'якої озимої. За фізичними властивостями тіста можна відмітити суттєвий вплив допосівної обробки насіння регуляторами росту $і$ бактеріальними препаратами на фоні удобрення $N_{25} P_{25} K_{25}$, $N_{50} P_{50} K_{50}, N_{75} P_{75} K_{75}$, які характеризуються високими показниками стійкості, опірності та еластичності тіста, низьким ступенем розрідження $i$ високою валориметричною оцінкою. Дослідженнями встановлено, збільшення об'сму хліба завдяки допосівної обробки насіння поліміксобактерином $(150 \mathrm{~m} / \mathrm{m})$ i діазофітом $(150 \mathrm{мл} / \mathrm{m})$.
\end{abstract}

Ключові слова: водовбирна здатність, час утворення тіста, стійкість до замішування, опірність тіста, розрідження, еластичність, валориметрична оцінка.

Постанова проблеми. Серед безлічі зернових культур, що дають людині продукти харчування, особливе значення 3 давніх пір належить пшениці. Хліб із пшеничного борошна відрізняється пористою, стійкою та еластичною м'якушкою і має високу поживність та приємний смак. Пшеничний хліб - один із головних і важливих продуктів харчування населення, в звязку з чим питання підвищення урожайності пшениці та поліпшення іiі якості не перестають бути предметом багаточисельних наукових досліджень. Одним із основних завдань підвищення хлібопекарських показників $є$ застосування внесення мінеральних добрив в оптимальнім співвідношенні та допосівної обробки насіння бактеріальними препаратами.

Аналіз основних досліджень і публікацій, у яких започатковано розв'язання проблеми. Важливими технологічними показниками, пов'язаними з кількістю і фізико-хімічними властивостями білкового комплексу клейковини, $є$ водовбирна здатність (ВВ3) борошна, час утворення тіста, стійкість до замішування, опірність, розрідження, еластичність, валориметрична оцінка. Всі ці властивості борошна проявляються під час виготовлення хліба й виражаються показниками обсягу та якості хліба. Водовбирна здатність залежить від сорту, вмісту й якості білка у борошні. Тривалість замішування тіста 3 борошна із вмістом 7,5 \% набагато більша, ніж із вмістом 11-13\%. Для борошна потрібно більше часу для отримання суцільної білкової сітки, а їі стійкість у процесі замішування буває кращою, ніж у борошні з вмістом білка 13 \% і більше. Погіршення фізичних властивостей тіста і хлібопекарських якостей зерна відмічено при високому вмістові білка - понад 17 \% [1]. Для характеристики хлібопекарських якостей зерна важливим $є$ сила борошна, пружність, збалансованість тіста, загальна валориметрична оцінка та розрідження тіста. Об'ємний вихід хліба з сильного борошна $\epsilon$ меншим, ніж із борошна нижчої сили. Розрідження тіста і валориметрична оцінка, зафіксовані фаринографом, дають чітке уявлення про формостійкість череневого хліба [2-5].

Головним методом оцінки якості зерна пшениці у лабораторних умовах є пробне випікання хліба, яке показує основні хлібопекарські властивості борошна, що виражається об'ємом випеченого хліба та якістю його м'якушки.

Мета досліджень та методика їх проведення. Мета роботи полягає у застосуванні передпосівної обробки насіння хімічними і біологічними препаратами та внесення повного удобрення для поліпшення фізичних і хлібопекарських властивостей зерна пшениці м'якої озимої.

Предметом досліджень був сорт Василина пшениці м'якої озимої, оброблений протруйником, біологічно активними речовинами. Облік урожайності проводили методом поділянкового обмолоту $з$ наступним очищенням зерна і перерахунком на $100 \%$ чистоту та на $14 \%$ вологість, які визначали відповідно до «Методики державного сортовипробування» [4]. Дослідження 3 пшеницею м'якою озимою сорту Василина проводили в умовах Лівобережного Лісостепу на базі дослідного поля Полтавського інституту агропромислового виробництва ім. М. І. Вавило- 
ва. Повторність - триразова, попередник - горох; норма висіву насіння - 5,0 млн схожих насінин на 1 га, глибина загортання насіння - 4-6 см. Сівбу проводили у третій декаді вересня (в залежності від погодних умов даного періоду в рік сівби) сівалкою С3-3,6. Перед сівбою насіння обробляли протруйником віал $(0,4$ л/т), рістстимулюючою речовиною вимпел (150 мл/т), агат- $25 \mathrm{~K}$ 40 г/т, а також сумісній обробці вимпел $(90$ мл/т) i агат-25К (25 г/т), вимпел (120 мл/т) i агат-25К $(60$ г/т), вимпел $(100$ мл/т) i агат-25К (20 г/т) та проводили передпосівну інокуляцію бактеріальними препаратами (поліміксобактерин і діазо- фіт) у дозі 150 мл/т із витратою робочої речовини 2 л/га. Навесні вносили азотне добриво по варіантах: $\mathrm{N}_{25}, \mathrm{~N}_{50}, \mathrm{~N}_{75}$ по мерзло-талому грунту, в період відновлення вегетації.

Результати досліджень. У ході наукових досліджень фізичні властивості тіста були одержані у результаті розшифрування фаринограми (табл. 1).

Головним показником, пов'язаним із фізичними властивостями, $€$ водовбирна здатність (BВ3), що дорівнює кількості води, витраченої для замішування тіста до потрібної консистенції. У сорту Василина даний показник варіював у межах від 62,2 до 71,5\%.

\section{1. Фізичні властивості тіста пиениці м'якої озимої (середнє за 2008-2010 рр.)}

\begin{tabular}{|c|c|c|c|c|c|c|c|c|}
\hline $\begin{array}{c}\text { Допосівна } \\
\text { обробка } \\
\text { насіння } \\
\text { (фактор А) }\end{array}$ & $\begin{array}{c}\text { Варіант } \\
\text { удобрення } \\
\text { (фактор В) }\end{array}$ & $\begin{array}{c}\text { Водо- } \\
\text { вбірна } \\
\text { здат- } \\
\text { ність, \% }\end{array}$ & $\begin{array}{c}\text { Час } \\
\text { утво- } \\
\text { рення } \\
\text { тіста, хв. }\end{array}$ & $\begin{array}{c}\text { Стій- } \\
\text { кість до } \\
\text { замішу- } \\
\text { вання, } \\
\text { хв. }\end{array}$ & $\begin{array}{c}\text { Опір- } \\
\text { ність } \\
\text { тіста, хв. }\end{array}$ & $\begin{array}{l}\text { Розрі- } \\
\text { дження } \\
\text { тіста, } \\
\text { од. ф. }\end{array}$ & $\begin{array}{c}\text { Еласти- } \\
\text { чність } \\
\text { тіста, мм }\end{array}$ & $\begin{array}{c}\text { Валори- } \\
\text { метрич- } \\
\text { на оцін- } \\
\text { ка, од. ф }\end{array}$ \\
\hline \multirow{5}{*}{$\begin{array}{c}\text { Без обробки } \\
\text { насіння - } \\
\text { контроль }\end{array}$} & Без добрив & 67,0 & 4,5 & 1,6 & 6,1 & 110 & 17,0 & 76,0 \\
\hline & $\mathrm{N}_{25} \mathrm{P}_{25} \mathrm{~K}_{25}$ & 64,9 & 3,3 & 2,5 & 5,8 & 76,6 & 16,6 & 72,3 \\
\hline & $\mathrm{N}_{50} \mathrm{P}_{50} \mathrm{~K}_{50}$ & 66,1 & 4,0 & 2,0 & 5,6 & 110 & 16,3 & 76,3 \\
\hline & $\mathrm{N}_{75} \mathrm{P}_{75} \mathrm{~K}_{75}$ & 67,7 & 4,7 & 3,0 & 7,4 & 113 & 16,0 & 77,6 \\
\hline & 3 т/га соломи $+\mathrm{N}_{10}$ & 64,8 & 4,3 & 3,2 & 7,6 & 93,3 & 17,6 & 76,3 \\
\hline \multirow{5}{*}{$\begin{array}{l}\text { Протруєння } \\
\text { насіння віа- } \\
\text { лом } 0,4 \text { л/т }\end{array}$} & Без добрив & 65,7 & 4,8 & 2,8 & 7,6 & 116 & 16,0 & 79,0 \\
\hline & $\mathrm{N}_{25} \mathrm{P}_{25} \mathrm{~K}_{25}$ & 68,7 & 4,3 & 1,5 & 5,8 & 106 & 13,0 & 79,0 \\
\hline & $\mathrm{N}_{50} \mathrm{P}_{50} \mathrm{~K}_{50}$ & 69,3 & 4,1 & 1,7 & 5,9 & 96,6 & 15,3 & 74,0 \\
\hline & $\mathrm{N}_{75} \mathrm{P}_{75} \mathrm{~K}_{75}$ & 71,5 & 4,1 & 1,5 & 5,6 & 90,0 & 14,0 & 80,3 \\
\hline & 3 т/га соломи $+\mathrm{N}_{10}$ & 67,4 & 4,6 & 2,8 & 7,5 & 63,3 & 14,6 & 79,3 \\
\hline \multirow{5}{*}{$\begin{array}{c}\text { Оброблене } \\
\text { насіння ре- } \\
\text { гуляторами } \\
\text { росту* }\end{array}$} & Без добрив & 69,8 & 4,1 & 2,6 & 6,8 & 90,0 & 19,0 & 88,6 \\
\hline & $\mathrm{N}_{25} \mathrm{P}_{25} \mathrm{~K}_{25}$ & 68,0 & 3,8 & 3,1 & 7,0 & 83,3 & 21,0 & 86,3 \\
\hline & $\mathrm{N}_{50} \mathrm{P}_{50} \mathrm{~K}_{50}$ & 69,7 & 5,1 & 3,5 & 8,6 & 76,6 & 22,6 & 88,0 \\
\hline & $\mathrm{N}_{75} \mathrm{P}_{75} \mathrm{~K}_{75}$ & 66,5 & 5,3 & 4,5 & 9,8 & 90,0 & 23,6 & 90,6 \\
\hline & 3 т/га соломи $+\mathrm{N}_{10}$ & 62,2 & 4,3 & 3,3 & 7,6 & 80,0 & 20,6 & 87,3 \\
\hline \multirow{5}{*}{$\begin{array}{c}\text { Оброблене } \\
\text { насіння бак- } \\
\text { теріальним } \\
\text { препаратом } \\
\text { поліміксо- } \\
\text { бактерин, } \\
150 \text { мл/т }\end{array}$} & Без добрив & 64,6 & 6,1 & 3,8 & 10,0 & 76,6 & 20,0 & 91,3 \\
\hline & $\mathrm{N}_{25} \mathrm{P}_{25} \mathrm{~K}_{25}$ & 67,7 & 6,5 & 3,3 & 9,8 & 63,3 & 22,3 & 90,6 \\
\hline & $\mathrm{N}_{50} \mathrm{P}_{50} \mathrm{~K}_{50}$ & 66,0 & 8,1 & 4,6 & 12,8 & 63,3 & 23,6 & 93,0 \\
\hline & $\mathrm{N}_{75} \mathrm{P}_{75} \mathrm{~K}_{75}$ & 64,1 & 8,8 & 5,1 & 14,0 & 53,3 & 24,3 & 89,6 \\
\hline & 3 т/га соломи $+\mathrm{N}_{10}$ & 66,3 & 6,5 & 3,6 & 10,1 & 70,0 & 22,0 & 88,6 \\
\hline \multirow{5}{*}{$\begin{array}{c}\text { Оброблене } \\
\text { насіння бак- } \\
\text { теріальним } \\
\text { препаратом } \\
\text { діазофіт, } \\
150 \text { мл/т }\end{array}$} & Без добрив & 64,1 & 5,8 & 3,5 & 9,3 & 80,0 & 20,3 & 93,6 \\
\hline & $\mathrm{N}_{25} \mathrm{P}_{25} \mathrm{~K}_{25}$ & 62,8 & 6,3 & 4,0 & 10,3 & 76,6 & 21,6 & 90,0 \\
\hline & $\mathrm{N}_{50} \mathrm{P}_{50} \mathrm{~K}_{50}$ & 67,6 & 6,8 & 4,5 & 11,3 & 70,0 & 24,0 & 94,0 \\
\hline & $\mathrm{N}_{75} \mathrm{P}_{75} \mathrm{~K}_{75}$ & 64,4 & 8,1 & 5,1 & 13,3 & 60,0 & 24,6 & 93,6 \\
\hline & 3 т/га соломи $+\mathrm{N}_{10}$ & 63,7 & 5,8 & 4,6 & 10,5 & 70,0 & 21,6 & 92,6 \\
\hline \multicolumn{2}{|c|}{$H_{\text {HIP }}$ 05 фактор $A$} & 3,24 & 1,10 & 0,89 & 1,67 & 19,7 & 1,94 & 6,24 \\
\hline \multicolumn{2}{|c|}{$H_{1 P}{ }_{05}$ фактор B } & 3,32 & 1,47 & 1,12 & 2,33 & 22,1 & 3,30 & 8,43 \\
\hline \multicolumn{2}{|c|}{ Взаємодї̈ $A B$} & 8,37 & 2,75 & 2,15 & 3,90 & 50,9 & 4,72 & 17,9 \\
\hline
\end{tabular}

Примітка: * без добрив оброблені вимпелом (150 мл/т), $\mathrm{N}_{25}$ - сумісної обробки вимпел (90 мл/т) $\mathrm{i}$ araт-25K (25 г/т), $\mathrm{N}_{50}-$ агат-25K (40 г/т), $\mathrm{N}_{75}$ - вимпел $\left(120\right.$ мл/т) і агат-25K (60 г/т), $\mathrm{N}_{10}-$ вимпел $(100$ мл/т) і агат-25K $(20$ г/т) 
Час утворення тіста - це період від початку замішування до моменту утворення гомогенного тіста. Тривалим даний показник спостерігався у сорту пшениці озимої з міцною клейковиною. Згідно з методичними вказівками, для випікання хліба без поліпшувачів тривалість замішування становила 3 хвилини. Проте цього виявилося замало, оскільки за цей час не вдавалося досягти утворення тіста заданої консистенції, - клейковина залишалася міцною і стримувала роботу дріжджів.

За роки досліджень середній показник цієї ознаки змінювався в межах від 3,3 до 8,8 хвилин. Спостерігаються відмінності між варіантами за величиною показника та мінливість в умовах вирощування. Сорт Василина характеризуються стабільним проявом цього показника, тоді як утворення тіста значно залежало від умов вирощування [3].
Стійкість тіста до замішування - час, протягом якого консистенція тіста не змінювалася.

Тривалий час стійкості свідчив про високу якість борошна. Дана ознака варіювала в межах $1,5-5,1$ хв $\left(\mathrm{HIP}_{05}=2,15\right.$ хв $)$.

Опірність тіста - це сума часу утворення i стійкості тіста. У сорту пшениці м'якої озимої даний показник знаходився у межах 5,6-14,0 хв. Найбільшу опірність тіста, встановлено за інокуляції насіння поліміксобактерином на фоні удобрення $\mathrm{N}_{75} \mathrm{P}_{75} \mathrm{~K}_{75}-14,0$ хв.

Окрім того встановлено меншу опірність; на високому рівні цей показник був у варіанті з обробкою діазофітом 10,3 хв, $\mathrm{N}_{25} \mathrm{P}_{25} \mathrm{~K}_{25}$, при внесення $\mathrm{N}_{50} \mathrm{P}_{50} \mathrm{~K}_{50}-11,3$ хв, а за збільшення норми внесення добрив до $\mathrm{N}_{75} \mathrm{P}_{75} \mathrm{~K}_{75}$ показник зріс (13,3 хв).

\section{2. Хлібопекарська оцінка якості хліба пшениці м'якої озимої (середнє за 2008-2010 рр.)}

\begin{tabular}{|c|c|c|c|}
\hline $\begin{array}{l}\text { Допосівна обробка } \\
\text { насіння (фактор А) }\end{array}$ & $\begin{array}{c}\text { Варіант удобрення } \\
\text { (фактор В) }\end{array}$ & Об'єм хліба, см ${ }^{3}$ & Загальна оцінка, бал \\
\hline \multirow{5}{*}{$\begin{array}{c}\text { Без обробки насіння - } \\
\text { контроль }\end{array}$} & Без добрив & 510 & 6,8 \\
\hline & $\mathrm{N}_{25} \mathrm{P}_{25} \mathrm{~K}_{25}$ & 534 & 7,0 \\
\hline & $\mathrm{N}_{50} \mathrm{P}_{50} \mathrm{~K}_{50}$ & 550 & 7,4 \\
\hline & $\mathrm{N}_{75} \mathrm{P}_{75} \mathrm{~K}_{75}$ & 544 & 7,2 \\
\hline & 3 т/га соломи $+\mathrm{N}_{10}$ & 520 & 7,1 \\
\hline \multirow{5}{*}{$\begin{array}{c}\text { Протруєння насіння } \\
\text { віалом } 0,4 \text { л/т }\end{array}$} & Без добрив & 565 & 7,5 \\
\hline & $\mathrm{N}_{25} \mathrm{P}_{25} \mathrm{~K}_{25}$ & 580 & 7,5 \\
\hline & $\mathrm{N}_{50} \mathrm{P}_{50} \mathrm{~K}_{50}$ & 604 & 8,2 \\
\hline & $\mathrm{N}_{75} \mathrm{P}_{75} \mathrm{~K}_{75}$ & 616 & 8,0 \\
\hline & 3 т/га соломи $+\mathrm{N}_{10}$ & 563 & 7,4 \\
\hline \multirow{5}{*}{$\begin{array}{l}\text { Оброблене насіння } \\
\text { регуляторами росту* }\end{array}$} & Без добрив & 590 & 7,6 \\
\hline & $\mathrm{N}_{25} \mathrm{P}_{25} \mathrm{~K}_{25}$ & 611 & 8,2 \\
\hline & $\mathrm{N}_{50} \mathrm{P}_{50} \mathrm{~K}_{50}$ & 628 & 8,0 \\
\hline & $\mathrm{N}_{75} \mathrm{P}_{75} \mathrm{~K}_{75}$ & 644 & 8,6 \\
\hline & 3 т/га соломи $+\mathrm{N}_{10}$ & 643 & 8,0 \\
\hline \multirow{5}{*}{$\begin{array}{c}\text { Оброблене насіння бак- } \\
\text { теріальним препаратом } \\
\text { поліміксобактерин, } \\
150 \text { мл/т }\end{array}$} & Без добрив & 601 & 7,8 \\
\hline & $\mathrm{N}_{25} \mathrm{P}_{25} \mathrm{~K}_{25}$ & 613 & 8,2 \\
\hline & $\mathrm{N}_{50} \mathrm{P}_{50} \mathrm{~K}_{50}$ & 650 & 8,6 \\
\hline & $\mathrm{N}_{75} \mathrm{P}_{75} \mathrm{~K}_{75}$ & 675 & 8,3 \\
\hline & 3 т/га соломи $+\mathrm{N}_{10}$ & 613 & 8,2 \\
\hline \multirow{5}{*}{$\begin{array}{l}\text { Оброблене насіння бак- } \\
\text { теріальним препаратом } \\
\text { діазофіт, } 150 \text { мл/т }\end{array}$} & Без добрив & 610 & 7,6 \\
\hline & $\mathrm{N}_{25} \mathrm{P}_{25} \mathrm{~K}_{25}$ & 623 & 8,3 \\
\hline & $\mathrm{N}_{50} \mathrm{P}_{50} \mathrm{~K}_{50}$ & 653 & 8,4 \\
\hline & $\mathrm{N}_{75} \mathrm{P}_{75} \mathrm{~K}_{75}$ & 670 & 8,4 \\
\hline & 3 т/га соломи $+\mathrm{N}_{10}$ & 643 & 8,6 \\
\hline \multicolumn{2}{|c|}{$H I P_{05}$ фактор A } & 28,4 & 0,34 \\
\hline \multicolumn{2}{|c|}{ HIP 05 фактор B } & 40,8 & 0,46 \\
\hline \multicolumn{2}{|c|}{ Взаємодї $A B$} & 65 & 0,75 \\
\hline
\end{tabular}

Примітка: * без добрив, оброблені вимпелом (150 мл/т), $\mathrm{N}_{25}$ - сумісної обробки вимпел (90 мл/т) i агат-25K (25 г/т), $\mathrm{N}_{50}$ - агат-25K (40 г/т), $\mathrm{N}_{75}$ - вимпел $\left(120\right.$ мл/т) і агат-25K $\left(60\right.$ г/т), $\mathrm{N}_{10}$ - вимпел $(100$ мл/т) і агат-25K $(20$ г/т). 
Еластичність тіста - показник, який характеризував ширину кривої фаринограми за консистенцією 500 од. ф. Дана ознака у сорту пшениці м'якої озимої за середніми даними знаходилася у межах 13-24,6 мм. Істотно більшу еластичність $\left(\mathrm{HIP}_{05}=4,72\right.$ мм $)$ мали у варіанті 3 внесенням основного добрива $\mathrm{N}_{75} \mathrm{P}_{75} \mathrm{~K}_{75}$ (23,6 мм), що перед посівом було оброблене вимпел + агат- 25 К. $\mathrm{y}$ варіанті обробки діазофітом даний показник був вищим за удобрення $\mathrm{N}_{75} \mathrm{P}_{75} \mathrm{~K}_{75}$ (24,6 мм).

Ступінь розрідження тіста - це величина падіння кривої після дванадцяти хвилин від початку розрідження. Показник залежав від сортових властивостей і зовнішніх умов вирощування. Він лежить в основі класифікації сорту пшениці на «сильні», «цінні» та «слабкі». Дана ознака у сорту варіювала в межах від 53,3 до 116 од. У наших дослідах встановлено, що величина цього показника залежить від сорту й умов року вирощування.

Валориметрична оцінка - це величина площі, яку займає фаринограма. За даним показником усі варіанти досліду належали до сильних пшениць (72,3-94 од.). За валориметричною оцінкою можна відмітити 93,6 од., що були оброблені діазофітом на фоні удобрення $\mathrm{N}_{75} \mathrm{P}_{75} \mathrm{~K}_{75}$, поліміксобактерином $-89,6$ од., які істотно відрізнялися $\left(\mathrm{HIP}_{05}=\right.$ 17,9 од.) за даним показником від протруєння насіння 74-80,3 од. Встановлено найбільший показник валориметричної оцінки - 94,0 од.

Прямим методом оцінки якості зерна пшениці в лабораторних умовах $є$ пробне випікання хліба. Це вказує на основні хлібопекарські якості борошна, що виражаються об'ємом випеченого хліба та якістю його м'якушки.

Об'ємний вихід хліба та його якість залежали від погодних умов року вирощування і сортових особливостей. Оцінюючи хлібопекарські власти-

\section{БІБЛІОГРАФІЯ}

1. Белеусова Е. М. Классификация сортов пшеницы по хлебопекарской силе // Селекция и семеноводство. - 1991. - № 2. - С. 16-19.

2. Доспехов Б. А. Методика полевого опыта (с основами статистической обработки результатов исследований). - 5-е изд., доп. и перераб. М.: Агропромиздат, 1985. - $351 \mathrm{c.}$

3. Лучной В. В., Панченко I. А. Результати вивчення хлібопекарських властивостей борошна вості сорту пшениці озимої, використовували методику без застосування поліпшувачів.

За середніми даними виділено варіанти удобрення та допосівної обробки насіння поліміксобактерином і діазофітом, що належали до сильних пшениць (675 $\left.\mathrm{cm}^{3}\right)$ (табл. 2).

За удобрення $\mathrm{N}_{50} \mathrm{P}_{50} \mathrm{~K}_{50} \mathrm{i}$ допосівної обробки насіння поліміксобактерином становить $650 \mathrm{~cm}^{3}$, $\mathrm{N}_{75} \mathrm{P}_{75} \mathrm{~K}_{75}-675 \mathrm{~cm}^{3}$, на високому рівні цей показник був за обробки діазофітом $\mathrm{N}_{25} \mathrm{P}_{25} \mathrm{~K}_{25}$ $623 \mathrm{~cm}^{3}, \mathrm{~N}_{50} \mathrm{P}_{50} \mathrm{~K}_{50}-653 \mathrm{~cm}^{3} \mathrm{~N}_{75} \mathrm{P}_{75} \mathrm{~K}_{75}-670 \mathrm{~cm}^{3}$, що суттєво відрізнялися $\left(\mathrm{HIP}_{05}=65 \mathrm{~cm}^{3}\right)$ від варіанту без обробки насіння.

Показник загальної оцінки якості хліба пшениці м'якої озимої варіював у межах 6,8-8,6 балів.

Найбільше значення встановлено за передпосівної обробки насіння поліміксобактерином на фоні удобрення $\mathrm{N}_{50} \mathrm{P}_{50} \mathrm{~K}_{50}-8,6$ бала, крім того відмічено суттєвий вплив протруєння насіння $\mathrm{N}_{50} \mathrm{P}_{50} \mathrm{~K}_{50}-8,2$ бала, що істотно перевищували варіанти без обробки насіння $\left(\mathrm{HIP}_{05}=0,75\right.$ бала).

Висновки. За фізичними властивостями тіста можна визначити суттєвий вплив допосівної обробки насіння регуляторами росту вимпел (90 мл/т) i агат-25К (25 г/т), агат-25К (40 г/т), вимпел (120 мл/т) і агат-25К (60 г/т), поліміксобактерином (150 мл/т) і діазофітом (150 мл/т) на фоні удобрення $\mathrm{N}_{25} \mathrm{P}_{25} \mathrm{~K}_{25}, \mathrm{~N}_{50} \mathrm{P}_{50} \mathrm{~K}_{50}, \mathrm{~N}_{75} \mathrm{P}_{75} \mathrm{~K}_{75}$, які характеризуються високими показниками стійкості, опірності та еластичності тіста, низьким ступенем розрідження і високою калориметричною оцінкою.

Дослідженнями встановлено збільшення об'єму хліба за рахунок допосівної обробки насіння поліміксобактерином (150 мл/т) і діазофітом $\left(150\right.$ мл/т) на фоні удобрення $\mathrm{N}_{50} \mathrm{P}_{50} \mathrm{~K}_{50}$, $\mathrm{N}_{75} \mathrm{P}_{75} \mathrm{~K}_{75}$.

озимої м'якої пшениці // Селекція і насінництво. - X., 2005. - № 91. - C. 130-135.

4. Методика державного сортовипробування сільськогосподарських культур / Під ред. В. В. Вовкодава. - Вип. 4. - К., 2001. - С. 29-30.

5. Подпрятов Г. І., Скалецька Л. Ф., Сеньков А. М. Технологія зберігання і переробки продукції рослинництва. / Практикум: Навч. пос. - К.: Вища освіта, 2004. - 272 c. 